\title{
Assessment of IgE and IgG4 binding capacities of cow's milk proteins selectively altered by proteases
}

Alexandre Charcosset ${ }^{1}$, Karine Adel-Patient ${ }^{1}$, Christophe Dupont $^{2}$ and Hervé Bernard ${ }^{1 *}$

${ }^{1}$ UMR Service de Pharmacologie et d'Immunoanalyse, CEA-INRA, Université Paris-Saclay, CEA de Saclay, F-91191, Gif-sur-Yvette, France

${ }^{2}$ Pediatric Gastroenterology Service, Hôpital Necker Enfants Malades, F-75015 Paris, France

*Corresponding author:

Hervé Bernard

Unité INRA d'Immuno-Allergie Alimentaire (UIAA)

IBiTecS/SPI - Bat 136

CEA de Saclay

91191 Gif-sur-Yvette cedex - FRANCE

Tel: (33) 169087998

Fax: (33) 169085907

herve.bernard-INRA@cea.fr 


\section{Supplementary Figure 1}
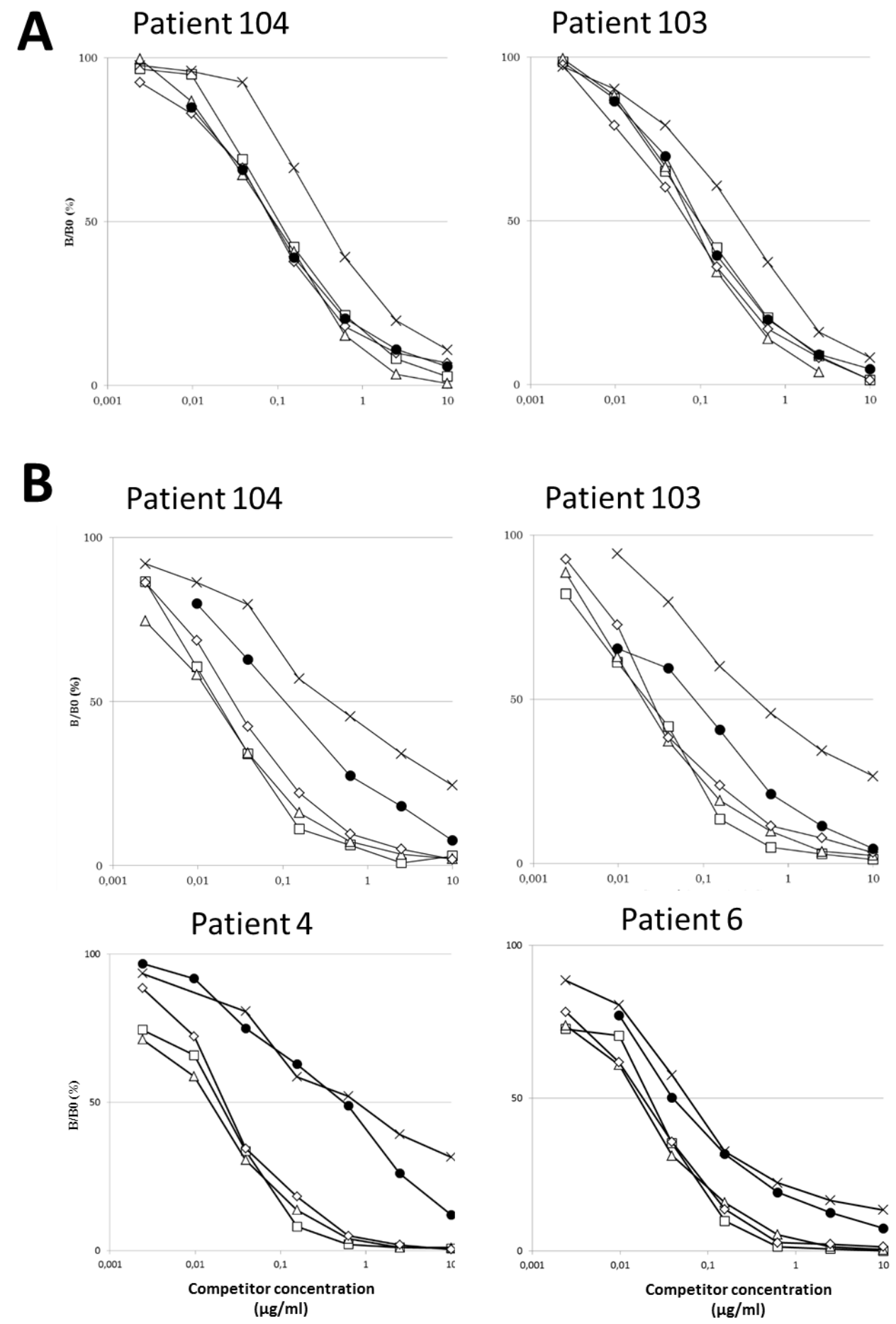

Suppl Fig 1/ Inhibition of the binding of IgE from CMA patients (\# 104 and 103) and CMtreated patients $(4,6)$ to $\beta$-LG $(A)$ or CN (B) by non-hydrolyzed cow's milk $(\square)$ or cow's milk hydrolyzed by plasmin $(\triangle)$, chymosin $(\diamond)$, a-chymotrypsin $(X)$ or pepsin $(\bullet)$. 